\title{
MEMAHAMI PROBLEMATIKA HAK PENGELOLAAN TANAH KOTA BATAM \\ DALAM RANGKA PENETAPAN BATAM \\ SEBAGAI KAWASAN EKONOMI KHUSUS
}

\author{
Nur Hadiyati \\ Program Pasca Sarjana \\ Fakultas Hukum Universitas Indonesia, Jalan Salemba Raya Nomor 4, Jakarta 10430 \\ Telepon : (021) 31909008, Fax : (021) 39899148 \\ Email: n.hadiyati@yahoo.co.id
}

\begin{abstract}
Land is part of the surface of the earth that plays an important role in the life of the people whose control is in the state, one of the forms of state control over land is the management rights. Batam Island is a sucessful example of management rights on land. However, with the presence of the local governemnt, many new issues about the management of law are feared to emerge. The Management Rights on Batam's land is obtained directly by the President who delegated to the Board of Mastery, so that the status of Batam land is divided into three namely: (1) the land above the management right by Enterprise (in Indonesian we called it Badan Pengusahaan); (2) land above the management of Batam City Local Government; (3) land managed by the state. Dualism of authority to manage Batam's Land caused problems as follows: Establishment of Kampung Tua, Status quo on land in Rempang Galang area, mismatch of land condition in Batam City with letter of decision by Ministry of Forestry, and the complexity of permit process, which hampered the development of Batam City. So by understanding how the implementation of Management Rights on Land will be enlightment to find a solution to the problem of dualism of land management authority and formulate the right policy in the framework of determining Batam as a Special Economic Zone.
\end{abstract}

Keywords: Batam, Management Rights, Agrarian, Special Economic Zone.

\begin{abstract}
ABSTRAK
Tanah merupakan bagian permukaan bumi yang memegang peranan penting dalam kehidupan masyarakat yang penguasaannya diatur oleh negara, salah satu wujud penguasaan negara atas tanah adalah Hak Pengelolaan. Pulau Batam adalah salah satu contoh HPL "sukses". Namun, dengan hadirnya pemerintah kotamadya Batam, dikhawtirkan banyak persoalan baru di bidang pertanahan yang muncul. Hak Pengelolaan Batam diperoleh langsung oleh Presiden yang dilimpahkan kepada Badan Penguasaan, sehingga status tanah Batam terbagi atas tiga yaitu : (1) tanah diatas Hak Pengelolaan Badan Pengusahaan; (2) tanah diatas pengelolaan Pemerintah Daerah Kota Batam; (3) tanah pengelolaan negara. Dualisme kewenangan pengelolaan lahan terjadi di Kota Batam dan menimbulkan permasalahan sebagai berikut : penetapan Kampung Tua, Status quo pada tanah dikawasan Rempang Galang, ketidakcocokan kondisi pertanahan di Kota batam dengan SK KEMENHUT, serta kerumitan proses perizinan, yangmana menghambat perkembangan Kota Batam. Maka dengan memahami bagaimana penyelenggaran Hak Pengelolaan dapat menemukan penyelesaian permasalahan dualisme kewenangan pengelolaan lahan dan merumuskan kebijakan yang tepat dalam rangka penetapan Batam sebagai Kawasan Ekonomi Khusus.
\end{abstract}

Kata Kunci: Batam, Hak Pengelolaan, Tanah, Agraria, Kawasan Ekonomi Khusus. 


\section{PENDAHULUAN}

Tanah berdasarkan Undang-Undang Undang-Undang Nomor 5 Tahun 1960 Tentang Pengaturan Pokok-Pokok Agraria dijabarkan sebagai bagian atas permukaan bumi. Tanah memegang peranan penting dalam kehidupan manusia sebagaimana diutarakan oleh Van Dijk", "Tanahlah yang merupakan modal yang terutama, dan untuk bagian terbesar dari Indonesia, tanahlah yang merupakan modal satu-satunya”. Paradigma ini yang kemudian menjadi dasar lahirnya Pasal 33 ayat (3) UUD NRI Tahun 1945, "Bumi dan air dan kekayaan alam yang terkandung di dalamnya dikuasai oleh negara dan dipergunakan untuk sebesar-besar kemakmuran rakyat". Negara memiliki hak untuk menguasai sumber daya termasuk didalamnya tanah untuk kemakmuran rakyat, berkenaan dengan tanah konsep hak menguasai ini salah satunya diejawantahkan dalam konsep Hak Pengelolaan (Selanjutnya disebut HPL).

Kota Batam merupakan bagian dari Kepulauan Riau sebagai provinsi dalam batas wilayah Negara Kesatuan Republik Indonesia yang merupakan daerah pemekaran dari daerah Riau tertanggal 24 September 2002 dan menjadi provinsi ke 32 berdasarkan Undang-Undang Nomor 25 Tahun 2002 tentang Pembentukan Provinsi Kepulauan Riau. Kota Batam memiliki luas wilayah 960,25 $\mathrm{Km}^{2}$ dengan batas wilayah sebelah utara dengan Selat Singapura, sebelah selatan dengan Kecamatan Senayang, sebelah timur dengan Kecamatan Bintan Utara, dan sebelah barat dengan Kabupaten Karimun dan Moro Kabupaten Karimun. Batam merupakan daerah yang memiliki HPL berbeda dibandingkan daerah lainnya. Batam, sebagai satu-satunya daerah yang mendapatkan HPL langsung oleh Presiden. ${ }^{2}$ HPL ini dilimpahkan berdasarkan Keputusan Presiden Nomor 41 Tahun 1973 tentang Daerah Industri Pulau Batam kepada sebuah Badan Otorita Pengelola yang dikemudian hari dialihkan kepada Badan Pengusahaan (selanjutnya disebut BP Batam). Status tanah di Batam terbagi atas tiga yaitu : pertama, tanah yang berada di atas pengelolaan BP Batam dalam kawasan perdagangan bebas atau free trade zone (FTZ) area; kedua, tanah yang berada di atas Pengelolaan Pemerintah Kota Batam; dan ketiga, tanah yang bukan berada di atas Hak Pengelolaan yang berada di atas tanah Negara selain dari Pulau Batam, status tanah kedua dan ketiga berada diluar kawasan perdagangan bebas atau free trade zone (FTZ) area. Berdasarkan status tanah demikian, maka terdapat tiga badan atau lembaga yang memiliki kewenangan dalam bidang pertanahan yakni : Pemerintah Kota Batam, BP Batam, dan Badan Pertanahan Nasional.

\section{Gambar 1.1 Peta Kota Batam}

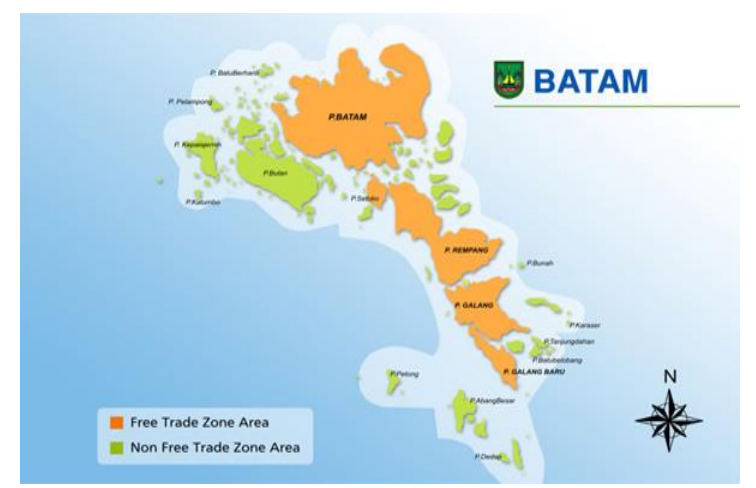

Danang Girindrawardana selaku Ketua Ombudsman Republik Indonesia mengatakan bahwa, "Batam ini unik, dari keunikan inilah membuat kita senang, karena kita bisa

\footnotetext{
${ }^{1}$ Zein, Ramli. "Hak Pengelolaan dalam Sistem UUPA". Jakarta : PT Rineka Cipta. 1995. hlm 7

${ }^{2}$ M Noor Marzuki menjabat sebagai Direktur Pengadaan Tanah Kementrian Agraria dan Tata Ruang Badan Pertanahan Nasional selaku Narasumber dalam acara Sosialisasi Status Lahan dan Hak Pengelolaan Kawasan Hutan di Provensi Kepulauan Riau, diakses pada Februari, 20, 2018. Dari www.ekon.go.id/berita/view/sosialisasi-status-lahan-dan.1458.html\#VdXTkdD-LqA
} 
mempelajari begitu banyak dinamika...". ${ }^{3}$ Hingga menjadi menarik untuk membahas dan memahami berkenaan dengan HPL yang diselenggarakan di Kota Batam.

\section{PEMBAHASAN}

Sejarah Hak Pengelolaan (HPL) imulai pada masa penjajahan Belanda, dengan istilah "in beheer" atau "beheerscrecht" yang berarti Hak Penguasaan. Hak ini diatur pertama kali dalam Peraturan Pemerintah Nomor 8 Tahun 1953 tentang Penguasaan Tanah Negara yang memuat beberapa ketentuan berkenaan dengan Hak Pengelolaan atau Hak Penguasaan sebagai berikut :

1. Merencanakan, peruntukkan, pengunaan tanah yang tersebut;

2. Menggunakan tanah tersebut untuk keperluan pelaksaan tugasnya;

3. Menerima yang pemasukan/ganti rugi dan atau uang wajib tahunan. ${ }^{4}$

Konsepsi pemberian hak penguasaan tanah secara filosofis didasarkan pada kebutuhan pribadi atau usahanya yang nyata serta kewajiban untuk menggunakannya. Berdasarkan Undang-Undang Nomor 5 Tahun 1960 tentang Peraturan Dasar Pokok-Pokok Agraria (Selanjutnya disebut UUPA) terdapat perintah untuk mengadakan perencanaan peruntukan dan penggunaan tanah (Pasal 14 UUPA), meletakkan kewajiban kepada mereka yang mempunyai tanah untuk menggunakan tanah yang dihaki-nya (Pasal 10 UUPA), kewajiban untuk memelihara, menambah kesuburan dan mencegah kerusakannya (Pasal 15 UUPA), larangan pemilikan dan penguaaan tanah yang berlebihan (Pasal 7 dan 17 UUPA), serta kebijakan dan ketentuan yang digariskan dalam Pasal 11, 12 dan 13 UUPA, merupakan penjabaran sifat fungsi sosial yang menunjukkan adanya unsur kebersamaan.

Asas-asas yang berlaku mengenai penguasaan tanah dan perlindungan hukum yang diberikan oleh Hukum Tanah Nasional terhadap para pemegang hak atas tanah, adalah $:^{5}$

1. Penguasaan dan penggunaan tanah oleh siapapun dan untuk keperluan apapun, harus dilandasi hak atas tanah yang disediakan oleh Hukum Tanah Nasional;

2. Penguasaan dan penggunaan tanah tanpa ada landasan haknya (illegal), tidak dibenarkan, bahkan diancam dengan sanksi pidana (UU 51 Prp 1960);

3. Penguasaan dan penggunaan tanah yang berlandaskan hak yang disediakan oleh Hukum Tanah Nasional, dilindungi oleh hukum terhadap gangguan dari pihak manapun, baik oleh sesama anggota masyarakat maupun oleh pihak penguasa sekalipun, jika gangguan tersebut tidak ada landasan hukumnya;

4. Hukum menyediakan berbagai sarana hukum untuk menanggulangi gangguan yang ada :

a. Gangguan oleh sesama anggota masyarakat; gugatan perdata melalui Pengadilan Negeri atau meminta perlindungan kepada

\footnotetext{
${ }^{3}$ Haluan Kepri, "Batam si cantik yang tercabik-cabik". Diakses pada April, 20, 2015. Dari http://haluankepri.com/batam/76021-batam-si-cantik-yang-tercabik-cabik.html

${ }^{4}$ Parlindungan, A.P. "Hak Pengelolaan Menurut Sistem U.U.P.A”. Bandung : Bandar Maju. 1994. hlm 6

5 Novlinda. "Kewenangan Pemerintah Daerah Di Bidang Pertanahan Berdasarkan Undang-Undang Nomor 32 Tahun 2004 Tentang Pemerintahan Daerah (Analisis Terhadap Kewenangan Bidang Pertanahan Antara Pemerintah Kota Batam Dan Otorita Pengembangan Daerah Industri Pulau Batam)". Tesis tidak diterbitkan : Universitas Sumatera Utara. 2010. hlm 33-34
} 
Bupati/Walikotamadya (UU 51 Prp 1960);

b. Gangguan oleh penguasa; gugatan melalui Pengadilan Umum atau Pengadilan Tata Usaha Negara;

5. Dalam keadaan biasa, diperlukan oleh siapapun dan untuk keperluan apapun (juga untuk proyek-proyek kepentingan umum) perolehan tanah yang menjadi hak seseorang, harus melalui musyawarah untuk mencapai kesepakatan, baik mengenai penyerahan tanahnya kepada pihak yang memerlukan maupun mengenai imbalannya yang merupakan hak pemegang hak atas tanah yang bersangkutan untuk menerimanya;

6. Tidak dibenarkan adanya paksaan dalam bentuk apapun oleh pihak manapun kepada pemegang hak atas tanah untuk menyerahkan tanah kepunyaannya dan atau menerima imbalan yang tidak disetujuinya, termasuk juga penggunaan lembaga penawaran pembayaran yang diikuti dengan konsinyasi pada Pengadilan Negeri (seperti diatur dalam Pasal 1404 KUHPerdata);

7. Dalam keadaan yang memaksa, jika tanah yang bersangkutan diperlukan untuk menyelenggarakan kepentingan umum, dan tidak mungkin menggunakan tanah yang lain, sedang musyawarah yang diadakan tidak berhasil memperoleh kesepakatan, dapat dilakukan pengambilan secara paksa, dalam arti tidak memerlukan persetujuan pemegang haknya, dengan menggunakan acara pencabutan hak atas tanah, yang diatur dalam UU 20/1961;

8. Dalam perolehan atau pengambilan tanah, baik atas kesepakatan bersama maupun melalui pencabutan hak, pemegang haknya berhak memperoleh imbalan atau ganti kerugian, yang bukan hanya meliputi tanahnya, melainkan juga kerugian-kerugian lain yang dideritanya sebagai akibat penyerahan tanah yang bersangkutan;

9. Bentuk dan jumlah imbalan atau ganti kerugian tersebut, juga jika tanahnya diperlukan untuk kepentingan umum dan dilakukan pencabutan hak, haruslah sedemikian rupa, hingga bekas pemegang haknya tidak mengalami kemunduran, baik dalam bidang sosial maupun tingkat ekonominya.

Ciri- Ciri dari Hak Pengelolaan berdasarkan Hukum Tanah Nasional, yaitu: ${ }^{6}$

1. Berdasarkan wewenang dan sifatnya, Hak Pengelolaan dapat dikategorikan sebagai hak atas tanah yang bersifat right to use;

2. Hak Pengelolaan hanya dapat dipunyai oleh badan hukum pemerintah yang bergerak di dalam pelayanan publik atau bidang bisnis yang tugas pokok dan fungsinya berkaitan dengan pengelolaan tanah;

3. Tanah Hak Pengelolaan digunakan untuk kepentingan mendirikan bangunan;

4. Hak Pengelolaan terjadi melalui penegasan konversi atau pemberian hak atas tanah negara;

5. Hak Pengelolaan wajib didaftarkan ke Kantor Pertanahan untuk diterbitkan sertipikat;

\footnotetext{
${ }^{6}$ Santoso, Urip. “Hukum Agraria: Kajian Komprehensif”. Jakarta: Kencana Prenadamedia Group. 2013. hlm. 171- 
6. Kewenangan pemegang Hak Pengelolaan ada yang beraspek publik dan beraspek privat;

7. Kewenangan pemegang Hak Pengelolaan ada yang bersifat internal dan bersifat eksternal;

8. Pemegang Hak Pengelolaan berwenang merencanakan peruntukan dan penggunaan tanahnya;

9. Pemegang Hak Pengelolaan berwenang menggunakan tanahnya untuk kepentingan pelaksanaan tugasnya;

10. Pemegang Hak Pengelolaan berwenang untuk menyerahkan bagian-bagian tanah Hak Pengelolaan kepada pihak ketiga dan/atau bekerja sama dengan pihak ketiga;

11. Tanah Hak Pengelolaan dapat dipergunakan sendiri oleh pemegang haknya dan dapat dipergunakan oleh pihak lain atas persetujuannya;

Hak pengelolaan merupakan hak lain berkenaan dengan tanah yang diatur dalam UUPA yang disebut secara tersirat dalam penjelasan umum, sehingga kelahiran HPL ditandai oleh Peraturan Menteri Agraria Nomor 9 Tahun 1965 tentang Pelaksanaan Konversi Hak Menguasai Negara dan Ketentuan-Ketentuan tentang Kebijaksanaan Selanjutnya. Dalam Pasal 2 disebutkan bahwa, "Jika tanah negara sebagai dimaksud Pasal 1, selain dipergunakan untuk kepentingan instansi-instansi itu sendiri, dimaksudkan juga untuk dapat diberikan dengan sesuatu hak kepada pihak ketiga, maka hak penguasaan tersebut diatas dikonversi menjadi hak pengelolaan sebagai dimaksud dalam Pasal 5 dan 7, yang berlangsung selama tanah tersebut dipergunakan untuk keperluan itu oleh instansi yang bersangkutan".
Pemegang Hak Pengelolaan memiliki kewenangan berdasarkan Peraturan Menteri Dalam Negeri Nomor 5 Tahun 1973 untuk :

1. Merencanakan, peruntukkan dan pengunaan tanah yang bersangkutan;

2. Menggunakan tanah tersebut untuk keperluan pelaksanaan tugas tugasnya;

3. Menyerahkan bagian-bagian dari tanah itu kepada pihak ketiga dengan Hak Pakai yang berjangka waktu 6 tahun;

4. Menerima uang pemasukan dan/atau uang wajib tahunan

Pemegang hak pengelolaan berdasarkan Pasal 1 ayat (1) Peraturan Menteri Dalam Negeri Nomor 1 Tahun 1977 tentang tentang Tata Cara Permohonan dan Penyelesaian Pemberian Hak Atas Bagian-Bagian Tanah Hak Pengelolaan serta Pendaftarannya, memiliki luas kewenangan untuk :

1. Merencanakan peruntukan dan penggunaan tanah yang bersangkutan;

2. Menggunakan tanah tersebut untuk keperluan pelaksanaan usahannya; dan

3. Menyerahkan bagian-bagian bagian tanah itu kepada pihak ketiga menurut persyaratan yang ditentukan oleh perusahaan pemegang hak tersebut, yang meliputi segi-segi peruntukan, penggunaan, jangka waktu dan keuangannya, dengan ketentuan pemberian hak atas tanah kepada pihak ketiga yang bersangkutan dilakukan oleh pejabat-pejabat yang berwenang, sesuai peraturan perundangan yang berlaku

Penggunaan istilah Hak Pengelolaan kemudian dapat ditemui dalam beberapa produk hukum di Indonesia selain dari yang dikeluarkan oleh Badan Pertanahan yakni Undang-Undang Nomor 16 Tahun 1985 tentang Rumah Susun atau saat sekarang ini 
Undang-Undang Nomor 20 Tahun 2001 tentang Rumah Susun yang menyebutkan istilah Hak Pengelolaan dalam Ketentuan Umum serta dalam pasal yang menjelaskan bahwa rumah susun hanya dapat dibangun diatas Hak Milik, Hak Guna Bangunan atau Hak Pakai Diatas Tanah Negara, Dan Hak Guna Bangunan atau Hak Pakai Diatas Hak Pengelolaan. Peraturan Pemerintah Nomor 24 Tahun 1997 tentang Pendaftaran Tanah yang menjadikan Hak Pengelolaan sebagai obyek pendaftaran tanah, Peraturan Pemerintah Nomor 40 Tahun 1996 tentang Hak Guna usaha, Hak Guna Bangunan, dan Hak Pakai atas Tanah kedua Peraturan Pemerintah yang disebutkan sebelumnya memberikan pengertian berkenaan dengan Hak Pengelolaan sebagai hak menguasai dari negara. Selanjutnya istilah Hak Pengelolaan dapat ditemukan dalam Undang-Undang Nomor 21 Tahun 1997 tentang Bea Perolehan Hak atas Tanah dan Bangunan yang menjadikan Hak Pengelolaan sebagai obyek pajak berdasarkan Bab II tentang Obyek Pajak dalam Pasal 2 ayat (3) huruf F. UndangUndang Nomor 21 Tahun 1997 tentang Bea Perolehan Hak atas Tanah dan Bangunan memberikan pengertian Hak Pengelolaan sebagai hak menguasai dari negara yang kewenangan pelaksanaannya sebagian dilimpahkan kepada pemegang haknya, antara lain berupa perencanaan peruntukan dan penggunaan tanah, penggunaan tanah untuk keperluan pelaksanaan tugasnya, penyerahan bagian-bagian dari tanah tersebut kepada pihak ketiga dan/atau bekerja sama dengan pihak ketiga
Bagan 2.1 Mekanisme Pemberian Hak

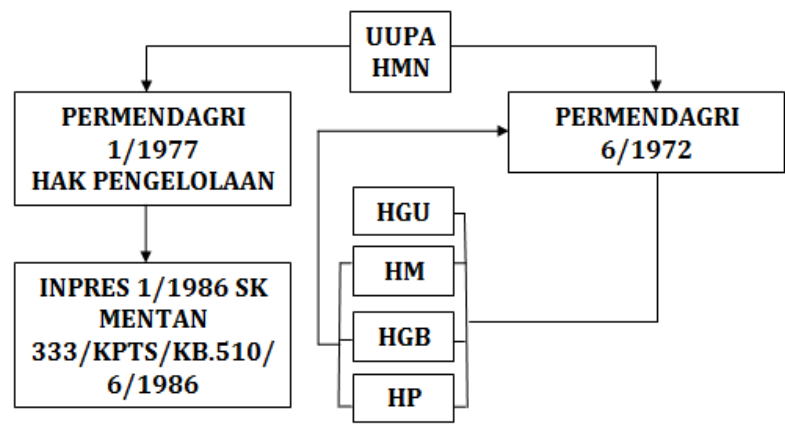

Boedi Harsono mengatakan bahwa Hak Pengelolaan adalah "gempilan" dari hak menguasai Negara. Pemegang Hak Pengelolaan mempunyai kewenangan menggunakan tanahnya untuk keperluan sendiri atau disediakan untuk digunakan bagi pihak lain yang memerlukan. Maria S.W. Sumardjono mengatakan bahwa Hak Pengelolaan merupakan "bagian" dari hak menguasai Negara yang (sebagian) kewenangannya dilimpahkan kepada pemegang Hak Pengelolaan. Dari dua pengertian diatas dapat diambil kesimpulan bahwa yang menjadi Objek dari Hak Pengelolaan adalah Tanah yang dikuasai oleh Negara

Menurut Urip Santoso, kewenangan yang terdapat dalam Hak Pengelolaan dapat bersifat pubik dan privat. ${ }^{7}$

1. Sifat publik, kewenangan untuk merencanakan peruntukan dan penggunaan tanah, mempergunakan tanah untuk keperluan pelaksanaan tugas dan usahanya. Kewenangan ini juga bersifat internal.

2. Sifat privat, kewenangan dalam hal menyerahkan bagian-bagian tanah Hak Pengelolaan kepada pihak ketiga dan/ atau bekerja sama. Dalam kewenangan

\footnotetext{
${ }^{7}$ Santoso, Urip. "Eksistensi Hak Pengelolaan dalam Hukum Tanah Nasional”. Mimbar Hukum Volume 24 No.2 Juni 2012. hlm 283.
} 
Hak Pengelolaan yang bersifat privat ini terkandung makna sifat Hak Pengelolaan yang eksternal

Selanjutnya R. Atang Ranoemihardja menjelaskan bahwa hak atas tanah yang dikuasai negara hanya dapat diberikan kepada badan hukum pemerintah atau pemerintah daerah baik dipergunakan untuk usahanya sendiri maupun untuk kepentingan pihak ketiga, pengertian dari R.Atang ini selain menegaskan hal yang menjadi objek hak pengelolaan juga menjabarkan berkenaan dengan subjek Hak Pengelolaan berdasarkan Pasal 67 Peraturan Menteri Agraria Nomor 9 Tahun 1999 Tentang Tata Cara Pemberian Dan Pembatalan Hak Atas Tanah Negara Dan Hak Pengelolaan adalah sebagai berikut :

1. Instansi pemerintah termasuk Pemerintah Daerah;

2. Badan Usaha Milik Negara;

3. Badan Usaha Milik Daerah;

4. PT. Persero;

5. Badan Otorita;

6. badan-badan hukum Pemerintah lainnya yang ditunjuk Pemerintah.

\section{Bagan 2.2 Jangka Waktu Hak Pakai}

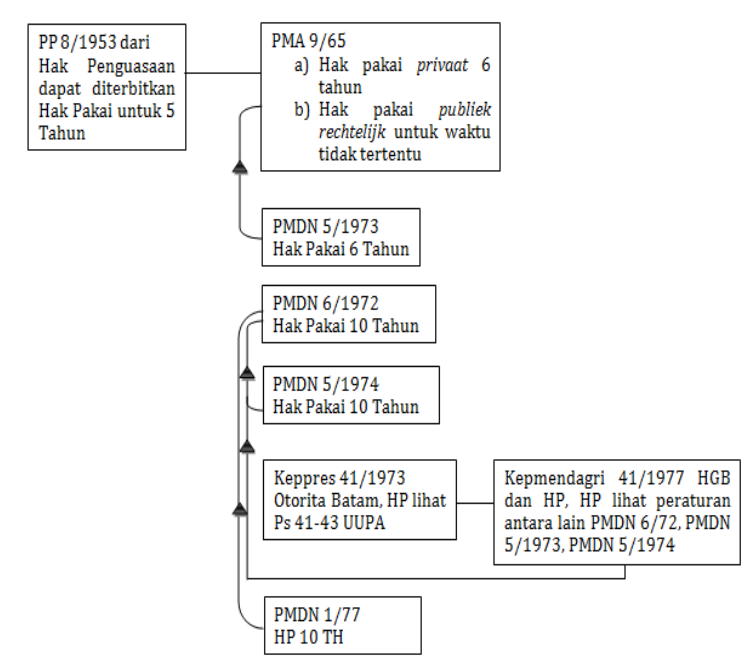

\section{Dualisme Pengelolaan Lahan di Kota Batam}

Pulau Batam adalah salah satu contoh HPL "sukses" ... Namun, dengan hadirnya pemerintah kotamadya Batam, dikhwatirkan banyak persoalan baru di bidang pertanahan yang muncul. ${ }^{8}$ Kota Batam yang dikenal dengan istilah bayi ajaib indonesia sebagai salah satu kawasan kompetitif di Asia Pasifik ${ }^{9}$ dan mampu menjadi mesin pencetak uang menemui jalan buntu pada permasalahan dualisme kewenangan pertanahan diakibatkan hak pengelolaan yang berada pada BP Batam sedangkan Pemerintah Kota Batam merasa memiliki kewenangan berdasarkan otonomi daerah.

Pada awalnya Batam tidak begitu dikenal luas oleh masyarakat. Sejarah pembangunan Batam dimulai dengan adanya kegiatan dari Perusahaan Negara pertambangan Minyak dan Gas Bumi Nasional (PN Pertamina) pada tahun 1969. Direktur Utama Pertamina (Pada saat itu, Ibnu Sutowo) ditetapkan sebagai penangungjawab pembangunan Batam. Presiden mengeluarkan Keputusan Presiden Nomor 65 Tahun 1970 tentang Pelaksanaan Proyek Pembangunan Pulau Batam (selanjutnya disebut Keppres Nomor 65 Tahun 1970). Tahap pengembangan Kota Batam dapat dibedakan menjadi empat periode, yaitu:

1. Periode persiapan;

2. Periode pembangunan infrastruktur dan investasi;

3. Periode pengembangan pembangunan prasarna dan penanaman modal;

4. Periode peningkatan sarana dan prasarana, penanaman modal serta kualitas lingungan.

\footnotetext{
${ }^{8}$ Rahmi, Elita. "Eksistensi Hak Pengelolaan Atas Tanah (HPL) dan Realitas Pembangunan Indonesia". Jurnal Dinamika Hukum Vol.10 No.3 September 2010. hlm 356

${ }^{9}$ Maharata, Apul D. "Membangun Indonesia, Studi Kasus Batam”, Jakarta : Pusataka Sinar Harapan. 2003. hlm 35
} 


\section{Bagan 2.3 Kronologis Pembangunan}

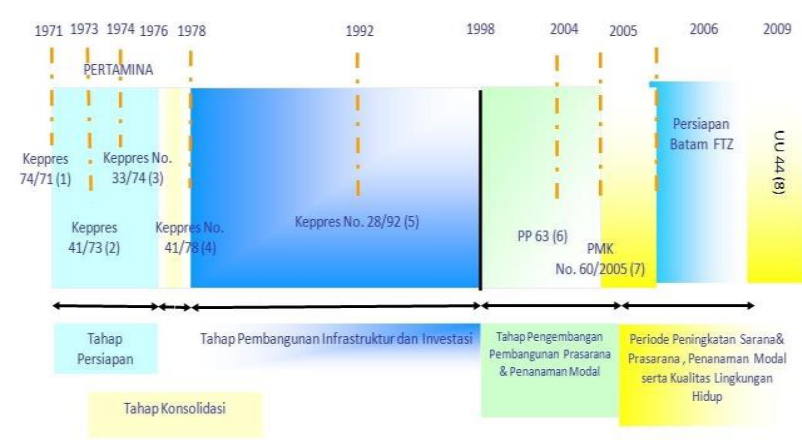

Titik balik dari perkembangan Kota Batam adalah pada tahun 1973 berdasarkan Keputusan Presiden Nomor 41 Tahun 1973 tentang Daerah Industri ${ }^{10}$ dengan dibentuknya Otorita Batam sebagai pemegang hak pelaksana tunggal pembangunan dengan hak pengelolaan sebagaimana termaktub dalam pasal 6 ayat (2) huruf a Keppres No 41 Tahun 1973 yang berbunyi, "Seluruh areal tanah yang terletak di Pulau Batam diserahkan, dengan hak pengelolaan, kepada Ketua Otorita Pengembangan Daerah Industri Pulau Batam". Pada pasal 6 ayat (2) huruf b dijelaskan bahwa Otorita Batam dalam hal ini dipimpin oleh seorang ketua dapat melakukan beberapa hal mengenai tanah yakni

1. Merencanakan peruntukan dan penggunaan tanah tersebut;

2. Menggunakan tanah tersebut untuk keperluan pelaksanaan tugasnya ;

3. Menyerahkan bagian-bagian dari tanah tersebut kepada pihak ketiga dengan hak-pakai sesuai dengan ketentuanketentuan Pasal sampai dengan Pasal 43 Undang-undang Pokok Agraria ;

4. Menerima uang pemasukan/ganti rugi dan uang wajib tahunan;
Hak pengelolaan berdasarkan Keppres No 41 Tahun 1973 kemudian dijabarkan melalui Keputusan Menteri Dalam Negeri Nomor 43 tahun 1977 tentang Pengelolaan dan Penggunaan Tanah di daerah Industri Pulau Batam, dimana areal yang dimaksud adalah tanah gugusan Pulau Janda berias - Pulau Tanjung Sau - Pulau Nginang, dan Pulau Kasom. Pada tahun 1992, areal tanah tersebut ditambah denga Pulau Rempang dan Pulang Galang berdasarkan Keputusan Presiden Republik Indonesia Nomor 28 tahun 1992 tentang Penambahan Wilayah Lingkungan Kerja Daerah Industri Pulau Batam Dan Penetapannya Sebagai Wilayah Usaha Kawasan Berikat.

Batam terus dikelola dimulai dari tahap persiapan dan perencanaan, pembangunan sarana dan prasana, serta pematangan dan era penanaman modal yang dibagi atas periodisasi masing-masing. Transisi politik di Indonesia juga berpengaruh pada perkembangan Batam dimana Batam beralih status dari KotaMadya Batam menjadi daerah otonom berdasarkan Undang-Undang Nomor 53 Tahun 1999 yang diperbaharui oleh Undang-Undang Nomor 13 Tahun 200 tentang Pembentukan Kabupaten Pelalawan, Kabupaten Rokan Hulu, Kabupaten Rokan Hilir, Kabupaten Siak, Kabupaten Karimun, Kabupaten Natuna, Kabupaten Kuantan Singigi, dan Kota Batam, peralihan status ini merupakan implikasi dari Undang-Undang Nomor 22 Tahun 1999 tentang Pemerintahan Daerah yang menjunjung tinggi semangat otonomi dimana memberi kekuasaan yang amat besar dan sebesar-besarnya kepada masing-masing daerah untuk mengatur urusan rumah tangganya sendiri sehingga mampu menjawab segala kebutuhan masyarakat yang ada didalam daerah otonom, pertanahan

\footnotetext{
${ }^{10}$ Daerah industri menurut National Industrial Zoning Committee's 1967 adalah tanah yang cukup luas, secara administratif dikontrol oleh seseorang atau lembaga yang cocok untuk kegiatan industri karena lokasi, topografi, ketersediaan infrastruktur, dan kemudahan aksesibilitas transportasi
} 
menjadi salah satu hal yang menjadi urusan pemerintahan daerah. Pemberian otonomi dibidang pertanahan kepada daerah kabupaten/kota ini merupakan suatu perubahan dasar dalam pelaksanaan hukum tanah nasional. ${ }^{11}$

Batam ditetapkan sebagai kawasan perdagangan bebas berdasarkan UndangUndang Nomor 36 Tahun 2000 tentang Kawasan Perdagangan Bebas dengan peraturan pelaksana Peraturan Pemerintah Nomor 5 Tahun 2011 jo Peraturan Pemerintah Nomor 46 Tahun 2007 tentang Kawasan Perdagangan Bebas dan Pelabuhan Bebas Kota Batam. 7 yang menjadi akhir dari Otorita Batam sebagai salah satu pelaksana pembangunan Kota Batam berdasarkan pasal 3 PP No 46 Tahun 2007 yang berbunyi :

Pasal 3 ayat (1) : Semua aset Otorita Pengembangan Daerah Industri Pulau Batam dialihkan menjadi aset Badan Pengusahaan Kawasan Perdagangan Bebas dan Pelabuhan Bebas Batam, kecuali aset yang telah diserahkan kepada Pemerintah Kota Batam, sesuai dengan Peraturan Perundang-undangan Pasal 3 ayat (2) Pegawai pada Otorita Pengembangan Daerah Industri Pulau Batam dialihkan menjadi pegawai pada Badan Pengusahaan Kawasan Perdagangan Bebas dan Pelabuhan Bebas Batam.

Berkenaan dengan pengelolaan pertanahan pun terjadi peralihan sebagaimana disebutkan dalam pasal 4 Peraturan Pemerintah Nomor 46 Tahun 2007 :

1) Hak Pengelolaan atas tanah yang menjadi kewenangan Otorita Pengembangan Daerah Industri Pulau Batam dan Hak Pengelolaan atas tanah yang menjadi kewenangan Pemerintah Kota Batam yang berada di Kawasan
Perdagangan Bebas dan Pelabuhan Bebas Batam sebagaimana dimaksud pada Pasal 1 ayat (2) beralih kepada Badan Pengusahaan Kawasan Perdagangan Bebas dan Pelabuhan Bebas Batam sesuai dengan peraturan perundang-undangan.

2) Hak-hak yang ada diatas Hak Pengelolaan atas tanah sebagaimana dimaksud pada ayat (1) tetap berlaku sampai masa berlakunya berakhir.

3) Untuk perpanjangan/pembaharuan hak setelah hak sebagaimana dimaksud pada ayat (2) berakhir, akan diberikan sesuai dengan Peraturan Perundangundangan

Sejak pembentukan Pemerintah Daerah Kota Batam, terdapat permasalahan yang belum terpecahkan, dimana terdapat benturan kepentingan otonomi daerah dengan kepentingan pertumbuhan ekonomi. Ada dua kapten dalam satu kapal. Di satu sisi ada Badan Pengelola (disebut badan pengusahaan sebagaimana diatur dalam Peraturan Pemerintah merupakan pergantian bentuk dari Otorita Batam), disisi lainnya ada juga kewenangan pemerintah daerah akibat konsekuensi dari otonomi daerah. ${ }^{12}$ Terdapat ketidakjelasan pengaturan hubungan kerjasama antara dua lembaga tersebut menurut hukum, telah ada pengamanahan dalam UU Nomor 53 Tahun 1999 jo UU Nomor 34 tahun 2008 tentang Pembentukan Kabupaten Pelalawan, Kabupaten Rokan Hulu, Kabupaten Rokan Hilir, Kabupaten Siak, Kabupaten Karimun, Kabupaten Natuna, Kabupaten Kuantan Singingi, dan

\footnotetext{
${ }^{11}$ Hutagalung, Arie S. "Tebaran Pemikiran Seputar Masalah Hukum Tanah”, Jakarta : Lembaga Pemberdayaan Hukum Indonesia. 2005. hlm. 40

${ }^{12}$ Rachman, Faisal. "FTZ BBK Dikelola Pemerintah Pusat". Diakses pada November, 23, 2015. Dari http://www.sinarharapan.co/news/read/150730145/ftz-bbk-dikelola-pemerintah-pusat
} 
Kota batam ${ }^{13}$ untuk adanya sebuah Peraturan Pemerintah (selanjutnya disebut PP) PP yang mengatur hubungan kerja antara lembaga pengelola dengan pemerintah, namun hingga saat ini pembentukan PP ini tidak terlaksana dan berhenti saat telah dikeluarkannya Surat Ka.OB Nomor 05/SKB/HK/VI/2000 tentang Pembentukan dan Susunan Tim Perancang Draft Peraturan Pemerintah tentang Pengaturan Hubungan kerja Pemerintah Kota Batam dengan Badan Otorita Batam. Namun, hingga saat ini belum diterbitkan PP yang mengatur hubungan kerja sama antara lembaga pengelola dengan pemerintah.

Dualisme dalam pengelolaan lahan di Batam belum terselesaikan meski telah terdapat sistem pelayanan terpadu satu pintu. Pemerintah pusat melalui penyerahan hak pengelolaan kepada BP Batam memberikan kewenangan berkenaan dengan perizinan dalam tataran pusat. Sementara berdasarkan otonomi daerah memberikan kewenangan kepada Pemerintah Daerah Kota Batam untuk mengeluarkan izin daerah. Hingga kini praktik dilapangan dalam hal ini Kota Batam, BP memiliki urusan tanggung jawab berkenaan fatwa planologi atau pengunaan lahan sedangkan Izin Mendirikan Bangunan (IMB) diterbitkan oleh Pemerintah Kota Batam. Beberapa permasalahan yang terlihat dalam dualisme ini dapat dilihat dalam contoh sebagai berikut : penetapan Kampung Tua, Status quo pada tanah dikawasan Rempang Galang, ketidakcocokan kondisi pertanahan di Kota batam dengan SK KEMENHUT, serta kerumitan proses perizinan yang terkadang menimbulkan tumpang tindih kepentingan ${ }^{14}$
Perang pernyataan di media massa tak terhindarkan. Wakil Wali Kota Batam (2001-2005) Asman Abnur, saat masih menjabat, pernah melontarkan pernyataan, BP harus dibubarkan. Demonstrasi massa yang ditengarai dibekingi masing-masing institusi untuk saling menjatuhkan wibawa "lawan" juga kerap berlangsung. Saling lempar tanggung jawab juga sering terjadi. Ketika banjir misalnya, telunjuk masyarakat mengarah ke Pemko sebagai pemerintah yang bertanggung jawab terhadap nasib warga dan kota. Tapi, Pemko tak mau disalahkan. Pasalnya, kewenangan pengalokasian lahan untuk properti dan usaha yang kerap dituding sebagai penyebab banjir ada di tangan BP. Kisruh juga terjadi soal status tempat pembuangan akhir (TPA) Telaga Punggur, yang ternyata masih milik BP. Pemko selaku pengelola sampah di Batam, setiap dua tahun harus memperpanjang izin ke BP, agar TPA tersebut bisa terus digunakan. "Pihak ketiga yang akan mengelola sampah di TPA juga menjadi ragu berinvestasi di sana karena status lahan bukan milik Pemko, tapi milik BP Batam ${ }^{15}$.

Pemerintah hingga saat ini berupaya menemukan solusi terkait permasalahan dualisme kewenangan pengelolaan lahan yang terjadi di Batam. Namun menurut Erwin Ismail selaku importir di Batam sejak diberlakukan FTZ di Batam per 1 April 2009, pergerakan usaha dikawasan industri menurun 30 hingga 40 persen. ${ }^{16}$ Bahkan berdasarkan perhitungan Kemendagri. selama sepuluh tahun terakhir, terjadi kehilangan Rp 20 triliun dari sektor perpajakan. Masalah yang belum

\footnotetext{
${ }^{13}$ Lihat Pasal 21 ayat (3) dan (4) UU Nomor 53 Tahun 1999 jo UU Nomor 34 tahun 2008 tentang Pembentukan Kabupaten Pelalawan, Kabupaten Rokan Hulu, Kabupaten Rokan Hilir, Kabupaten Siak, Kabupaten Karimun, Kabupaten Natuna, Kabupaten Kuantan Singingi, dan Kota batam

${ }^{14}$ Hasil wawancara dengan Bapak Iman Setiawan, S.H selaku Kasubid Bantuan Hukum Pemerintahan Kota Batam

${ }^{15}$ Batam Pos. "Satu kapal dua nahkoda", dari http://issuu.com/majalahbatampos/docs/edisi-20

${ }^{16}$ Tempo. "Impor Barang Menurun Sejak FTZ diberlakukan di Batam". Diakses pada Februari, 2, 2016. Dari http://bisnis.tempo.co/impor-barang-menurun-sejak-ftz-diberlakukan-di-batam
} 
terselesaikan ini sempat diajukan uji materiil oleh seorang masyarakat bernama Ta'In Komari yang menguji Undang-Undang Nomor 44 Tahun 2007 tentang Penetapan Perppu No. 1 Tahun 2007 tentang Perubahan Atas UU 36 Tahun 2000 Tentang Penetapan Perppu No. 1 Tahun 2000 tentang Kawasan Perdagangan Bebas dan Pelabuhan Bebas kepada Mahkamah Konstitusi karena dianggap mengancam proses pembangunan dan penyelenggaraan pemerintahan di Kota Batam sebagai daerah otonom. ${ }^{17}$ Pemasalahan ini selain diakibatkan kekosongan hukum juga telah dipengaruhi kepentingan politik dan ego sektoral. ${ }^{18}$

Muncul gagasan untuk menetapkan Batam sebagai Kawasan Ekonomi Khusus sebagai pergantian bentuk dari Kawasang Perdagangan Bebas atau Free Trade Zone area (FTZ), sekitar pada tahun 2006 Batam telah dikaji secara komprehensif berkenaan dengan kesiapan untuk ditetapkan sebagai kawasan ekonomi khusus. Bahkan kajian akademis tentang kesiapan Batam sebagai Kawasan Ekonomi Khusus telah diserahkan kepada pemerintah sebagai bahan atau narasumber untuk kelak menjadikan Batam sebagai KEK. Dalam laporan tersebut disebutkan bahwa untuk menjadikan Batam sebagai suatu kawasan dalam kategori kelas dunia, maka Batam harus memberikan pelayanan kelas dunia, baik dalam perijinan, perpajakan dan kepabeanan. Selain itu kawasan ini juga dapat memberikan fasilitas keamanan dunia, memiliki infrastruktur kelas dunia, baik untuk fasilitas jalan raya, pelabuhan, airport, transportasi, telekomunikasi, listrik. ${ }^{19}$
"Untuk menjadikan Batam, Bintan, Karimun (BBK) sebagai KEK, maka nantinya payung hukum atas eksistensi BBK sebagai KEK harus benar-benar diatur secara komprehensif dalam RUU KEK mendatang. Jangan sampai pengalaman FTZ di Batam dalam sistem hukum terulang kembali di KEK... Kekhawatiran senada juga diungkapkan oleh Neltje Saly selaku Kepala Pusat Penelitian Pengembangan Sistem Hukum Nasional Departemen Hukum dan HAM yang mengatakan bahwa dua kendala besar yang harus dibenahi yaitu aspek legalitas dan kualitas kelembagaan pemerintah." 20

Maka terdapat beberapa hal yang perlu diperhatikan sebagai bahan pertimbangan perumusan kebijakan Batam sebagai Kawasan Ekonomi Khusus.

1. Luas wilayah serta batas dari lokasi KEK, Kota Batam dalam Peraturan Daerah Nomor 2 Tahun 2004 tentang Rencana Tata Ruang dan Wilayah Kota Batam Tahun 2004 - 2014 telah memberikan alokasi lahan untuk kawasan khusus, kemudian dari pada itu Dewan Kawasan serta Tim KEK telah menetapkan bahwa Kawasan Industri akan dimasukkan kedalam bagian dari lokasi KEK

2. Jenis zona yang akan dilaksanakan oleh kawasan ekonomi khusus yang ditetapkan. KEK Kota Batam akan menjadi Zona Industri, hal ini dilandasi oleh Perindustrian menjadi

\footnotetext{
${ }^{17}$ ASH. "Warga Batam Persoalkan Aturan Kawasan Pelabuhan Bebas". Diakses pada Februari, 2, 2016. Dari http://www.hukumonline.com/berita/baca/lt514ae15d001a8/warga-batam-persoalkan-aturan-kawasanpelabuhan-bebas.

${ }^{18}$ Hasil wawancara dengan Bapak Iman Setiawan, S.H selaku Kasubid Bantuan Hukum Pemerintahan Kota Batam

${ }^{19}$ Lihat Final Report Mempersiapkan Batam Sebagai Kawasan Ekonomi Khusus. Jakarta 27 Desember 2006. CSIS. Jakarta.

${ }^{20}$ Media Indonesia. 11 September 2007. Kawasan Khusus Hanya Retorika, hlm. 14
} 
penyumbang terbesar

perekonomian Kota Batam

Tabel 2.1 : Share PDRB ADHK ${ }^{21} 2000$

\begin{tabular}{|c|c|c|c|c|c|}
\hline No & Seltor & 2010 & 2011 & 2012 & $2013^{*}$ \\
\hline 1 & Pertanian & $1,18 \%$ & $1,18 \%$ & $1,16 \%$ & $1,12 \%$ \\
\hline 2 & Pertanbangan dan Pengalian & $0,14 \%$ & $0,13 \%$ & $0,12 \%$ & $0,12 \%$ \\
\hline 3 & Industri Pengolahan & $61,64 \%$ & $60,69 \%$ & $59,92 \%$ & $58,99 \%$ \\
\hline 4 & Listrik, Gas dan Air Bersih & $0,65 \%$ & $0,67 \%$ & $0,66 \%$ & $0,67 \%$ \\
\hline 5 & Bangunan & $2,81 \%$ & $2,90 \%$ & $2,95 \%$ & $3,02 \%$ \\
\hline 6 & Perdagangan, Hotel dan Restoran & $24,80 \%$ & $25,72 \%$ & $26,53 \%$ & $27,40 \%$ \\
\hline 7 & Pengangkutan \& Korunikasi & $3,05 \%$ & $3,06 \%$ & $3,06 \%$ & $3,07 \%$ \\
\hline 8 & $\begin{array}{c}\text { Keuangan, Persewaan, dan jasa } \\
\text { Perusahaan }\end{array}$ & $4,48 \%$ & $4,44 \%$ & $4,41 \%$ & $4,43 \%$ \\
\hline 9 & Jasa-jasa & $1,25 \%$ & $1,21 \%$ & $1,19 \%$ & $1,18 \%$ \\
\hline
\end{tabular}

3. Kelembagaan dalam KEK, dalam hal ini berkenaan dengan sejarah perkembangan Kota Batam yang memiliki permasalahan berkenaan dengan tumpah tindih kewenangan antar lembaga yakni BP Batam dan Pemko Batam. Maka, diperlukan batasan yang jelas terkait lembaga berserta dengan tugas dan fungsi sebagai diatur dalam peraturan perundang-undangan

4. Ketentuan peralihan, hal-hal yang berkaitan dengan peralihan status dari FTZ menuju KEK, teerutama berkenaan dengan BP Batam. Dalam ini perlu dijabarkan berkenaan dengan mekanisme pembubaran, peralihan tugas, fungsi, dan aset yang sebelumnya dikelola oleh BP Batam.

\section{KESIMPULAN}

Tanah sebagai sumber daya alam yang dimiliki manusia dikuasai oleh negara, salah satu perwujudan dari penguasaan ini adalah adanya Hak Pengelolaan. Hak Pengelolaan (HPL) berasa dari istilah bahasa Belanda "in beheer" atau "beheerscrecht" yang berarti
Hak Penguasaan. Hak ini diatur pertama kali dalam Peraturan Pemerintah Nomor 8 Tahun 1953 tentang Penguasaan Tanah Negara. Obyek dari Hak Pengelolaan adalah tanah yang dikuasai oleh negara sedangkan subjek dari Hak Pengelolaan adalah : 1) Instansi pemerintah termasuk Pemerintah Daerah; 2) Badan Usaha Milik Negara; 3) Badan Usaha Milik Daerah; 3)PT. Persero; 4) Badan Otorita; 5) Badan-badan hukum Pemerintah lainnya yang ditunjuk Pemerintah. Pengaturan Hak Pengelolaan dapat ditemukan baik dalam peraturan yang dikeluarkan oleh Badan Pertanahan atau produk perundang-undangan lainnya.

Batam merupakan daerah yang memiliki HPL berbeda dibandingkan daerah lainnya. Batam, sebagai satu-satunya daerah yang mendapatkan HPL langsung oleh Presiden. Kota Batam memiliki luas wilayah sebesar 715 KM2 dengan jumlah penduduk 1.164.352 juta. Batam ditetapkan sebagai daerah industri Titik berdasarkan Keputusan Presiden Nomor 41 Tahun 1973 tentang Daerah Industri dengan dibentuknya Otorita Batam (yang kemudian berganti menjadi Badan Pengusahaan ) sebagai pemegang hak pelaksana tunggal pembangunan. Selanjutnya seriring perkembangan politik di Indonesia, dibentuklah pemerintahan daerah di Kota Batam. Kota Batam mulai menemui permasalahan dualisme kewenangan berkenaan dengan pertanahan dimana terdapat 3 Instansi yang bekerja yakni Kantor Pertanahan, Pemerintah Daerah Kota Batam, dan Badan Pengusahaan.

Permasalahan ini belum menemukan solusi, Batam yang dengan istilah bayi ajaib indonesia sebagai salah satu kawasan kompetitif di Asia Pasifik dan mampu

\footnotetext{
${ }^{21}$ PDRB ADHK (Produk Domestik Regional Bruto atas Dasar Harga Konstan) digunakan untuk mengetahui pertumbuhan ekonomi dari tahun ke tahun yang kemudian menunjukkan laju pertumbuhan ekonomi secara keseluruhan. Data PDRB ADHK lebih menjabarkan berkenaan dengan perkembangan produksi riil barang dan jasa yang dihasilkan unit usaha dalam kegiatan perekonomian
} 
menjadi mesin pencetak uang menemui jalan buntu, Perkembangan ekonomi di Kota Batam menjadi stagnan, menurut Erwin Ismail selaku importir di Batam sejak diberlakukan FTZ di Batam per 1 April 2009, pergerakan usaha dikawasan industri menurun 30 hingga 40 persen, bahkan berdasarkan perhitungan Kemendagri. selama sepuluh tahun terakhir, terjadi kehilangan Rp 20 triliun dari sektor perpajakan.

Rancangan Kota Batam sebagai Kawasan Ekonomi Khusus diharapkan mampu menjadi permasalahan berkenaan dengan dualisme kewenangan di bidang pertanahan yang berdampak pada pertumbuhan ekonomi Kota Batam. sekitar pada tahun 2006 Batam telah dikaji secara komprehensif berkenaan dengan kesiapan untuk ditetapkan sebagai kawasan ekonomi khusus. Untuk menjadikan Batam, Bintan, Karimun (BBK) sebagai Kawasa Ekonomi Khusus, maka nantinya payung hukum atas eksistensi BBK sebagai KEK harus benar-benar diatur secara komprehensif.

\section{DAFTAR PUSTAKA}

\section{Peraturan Perundang-Undangan}

Undang-Undang Dasar Negara Republik Indonesia Tahun 1945

Undang Nomor 5 Tahun 1960 tentang Peraturan Dasar Pokok-Pokok Agraria

Undang-Undang Nomor 23 Tahun 2014 tentang Pemerintah Daerah sebagaimana diubah dengan UndangUndang Nomor 9 Tahun 2015 tentang Perubahan Kedua Undang- Undang Nomor 23 Tahun 2014 tentang Pemerintah Daerah

Undang-Undang Nomor 39 Tahun 2009 tentang Kawasan Ekonomi Khusus

Undang-Undang Republik Indonesia Nomor 53 Tahun 1999 Tentang Pembentukan Kabupaten Pelalawan, Kabupaten Rokan Hulu, Kabupaten Rokan Hilir,
Kabupaten Siak, Kabupaten Karimun, Kabupaten Natuna, Kabupaten Kuantan Singingi, Dan Kota Batam, sebagaimana Diubah Dengan UndangUndang Republik Indonesia Nomor 13 Tahun 2000 Tentang Perubahan Atas Undang-Undang Nomor 53 Tahun 1999 Tentang Pembentukan Kabupaten Pelalawan, Kabupaten Rokan Hulu, Kabupaten Rokan Hilir, Kabupaten Siak, Kabupaten Karimun, Kabupaten Natuna, Kabupaten Kuantan Singingi, Dan Kota Batam, sebagaimana Diubah Dengan Undang-Undang Republik Indonesia Nomor 34 Tahun 2008 Tentang Perubahan Ketiga Atas Undang-Undang Nomor 53 Tahun 1999 Tentang Pembentukan Kabupaten Pelalawan, Kabupaten Rokan Hulu, Kabupaten Rokan Hilir, Kabupaten Siak, Kabupaten Karimun, Kabupaten Natuna, Kabupaten Kuantan Singingi, Dan Kota Batam

Undang-Undang Nomor 21 Tahun 1997 tentang Bea Perolehan Hak atas Tanah dan Bangunan yang menjadikan Hak Pengelolaan sebagai obyek pajak

Undang-Undang Nomor 20 Tahun 2001 tentang Rumah Susun

Peraturan Pemerintah Nomor 8 Tahun 1953 tentang Penguasaan Tanah Negara

Peraturan Pemerintah Nomor 40 Tahun 1996 tentang Hak Guna usaha, Hak Guna Bangunan, dan Hak Pakai atas Tana

Peraturan Pemerintah Nomor 24 Tahun 1997 tentang Pendaftaran Tanah

Peraturan Pemerintah Nomor 38 Tahun 2007 tentang Pembagian urusan Pemerintah antara Pemerintah, Pemerintah Daerah Provinsi dan Pemerintah Daerah Kabupaten/Kota

Peraturan Pemerintah Nomor 5 Tahun 2011 jo Peraturan Pemerintah Nomor 46 Tahun 2007 tentang Kawasan Perdagangan 
Bebas dan Pelabuhan Bebas Kota Urip Santoso, "Hukum Agraria: Kajian Batam

Peraturan Presiden Nomor 87 Tahun 2011 tentang Rencana Tata Ruang Kawasan Bintan, Kawasan Batam, dan Kawasan Karimun

Peraturan Daerah Kota Batam Nomor 2 Tahun 2004 tentang Rencana Tata Ruang Wilayah Kota Batam Tahun 2004-2014

Keputusan Presiden Nomor 41 Tahun 1973 tentang Daerah Industri

Peraturan Menteri Agraria Nomor 9 Tahun 1965 tentang Pelaksanaan Konversi Hak Menguasai Negara dan KetentuanKetentuan tentang Kebijaksanaan Selanjutnya

Peraturan Menteri Dalam Negeri Nomor 1 Tahun 1977 tentang tentang Tata Cara Permohonan dan Penyelesaian Pemberian Hak Atas Bagian-Bagian Tanah Hak Pengelolaan sertaPendaftarannya

Peraturan Menteri Agraria Nomor 9 Tahun 1999 Tentang Tata Cara Pemberian Dan Pembatalan Hak Atas Tanah Negara Dan Hak Pengelolaan

\section{Buku}

A.P Parlindungan, "Hak Pengelolaan Menurut Sistem U.U.P.A”, Bandung : Bandar Maju, 1994

Apul D Maharaja, "Membangun Indonesia, Studi Kasus Batam”, Jakarta : Pusataka Sinar Harapan, 2003

Arie S. Hutagalung, "Tebaran Pemikiran Seputar Masalah Hukum Tanah", Jakarta : Lembaga Pemberdayaan Hukum Indonesia, 2005

Notonagoro, "Politik Hukum dan Pembangunan Agraria", Jakarta : Bina Aksara, 1984

Ramli Zein, "Hak Pengelolaan dalam Sistem UUPA", Jakarta : PT Rineka Cipta, 1995

Komprehensif", Jakarta: Kencana Prenadamedia Group, 2013

Yose Rizal Damuari dkk., Kawasan Ekonomi Khusus dan Strategis Indonesia : Tinjauan atas Peluang dan Permasalahan, Jakarta : Centre for Strategic and International Studies, 2015, hlm. 32

\section{Jurnal}

Ahmad Redi, "Dinamika Konsepsi Penguasaan Negara Atas Sumber Daya Alam", Jurnal Konstitusi, Volume 12, Nomor 2, Juni 2015

Elita Rahmi. "Eksistensi Hak Pengelolaan Atas Tanah (HPL) dan Realitas Pembangunan Indonesia", Jurnal Dinamika Hukum Vol.10 No.3 September 2010

Nur Hadiyati. "Perencanaan Penetapan Batam sebagai Kawasan Ekonomi Khusus dalam Kerangka Otonomi Daerah". Jurnal Mahasiwa Fakultas Hukum Universitas Brawijaya. 2016

Urip Santoso. "Eksistensi Hak Pengelolaan dalam Hukum Tanah Nasional". Mimbar Hukum Volume 24 No.2 Juni 2012.

\section{Internet}

ASH. "Warga Batam Persoalkan Aturan Kawasan Pelabuhan Bebas". Diakses pada Februari, 2, 2016. Dari http://www.hukumonline.com/berita/ba ca/lt514ae15d001a8/warga-batampersoalkan-aturan-kawasan-pelabuhanbebas.

Batam Pos. "Satu kapal dua nahkoda", dari http://issuu.com/majalahbatampos/docs ledisi-20

Faisal Rachman. "FTZ BBK Dikelola Pemerintah Pusat". Diakses pada November, 23, 2015. Dari 
http://www.sinarharapan.co/news/read/ 150730145/ftz-bbk-dikelolapemerintah-pusat

Haluan Kepri, "Batam si cantik yang tercabikcabik". Diakses pada April, 20, 2015. Dari http://haluankepri.com/batam/76021batam-si-cantik-yang-tercabikcabik.html

Tempo. "Impor Barang Menurun Sejak FTZ diberlakukan di Batam". Diakses pada Februari, 2, 2016. Dari http://bisnis.tempo.co/impor-barangmenurun-sejak-ftz-diberlakukan-dibatam

\section{Sumber Lain}

Final Report Mempersiapkan Batam Sebagai Kawasan Ekonomi Khusus. Jakarta 27 Desember 2006. CSIS. Jakarta

Media Indonesia. 11 September 2007. Kawasan Khusus Hanya Retorika

Isdian A. "Akibat Hukum Insinkronisasi Pengaturan Bidang Pertanahan (Studi Kasus Penerbitan Surat Keputusan Menteri Kehutanan Nomor SK.463/Menhut-II/2013 di Kota Batam)". Tesis tidak diterbitkan : Universitas Brawijaya. 2014

Novlinda. "Kewenangan Pemerintah Daerah Di Bidang Pertanahan Berdasarkan Undang-Undang Nomor 32 Tahun 2004 Tentang Pemerintahan Daerah (Analisis Terhadap Kewenangan Bidang Pertanahan Antara Pemerintah Kota Batam Dan Otorita Pengembangan Daerah Industri Pulau Batam)". Tesis tidak diterbitkan : Universitas Sumatera Utara. 2010

Nur Hadiyati. "Kewenangan Pemerintah Daerah Dalam Bidang Pertanahan Berdasarkan Undang-Undang Nomor 23 Tahun 2014 Tentang Pemerintahan Daerah : Studi Di Pemerintah Kota
Batam" Laporan Kuliah Kerja Lapangan tidak diterbitkan : Universitas Brawijaya 2015. 